\title{
Des progrès significatifs en radioprotection
}

Dans ce numéro 1 de l'année 2020 de Radioprotection, nous publions des progrès significatifs en radioprotection dans le domaine médical et dans la phase post-accidentelle d'un accident nucléaire.

L'article de Teriitehau et al. (2020), est intitulé «Réduction de la dose au patient lors d'une vertébroplastie percutanée sous scanner: impact d'un nouveau système de navigation assisté par ordinateur ». Ce nouveau système de navigation utilise un générateur de champ électromagnétique intégré au référentiel du patient et un récepteur magnétique intégré dans un guide porteaiguille. Ce système de navigation permet une insertion précise et sûre de l'aiguille de vertébroplastie percutanée sous scanner et en conséquence une réduction significative de l'exposition du patient et de la durée de la procédure. Ce système de navigation est de plus en plus utilisé dans bien d'autres procédures de radiologie interventionnelle et il marque une rupture en radioprotection dans le domaine médical.

Un second article de Maître et al. (2020), est intitulé «La gestion des biens de consommation contaminés au Japon depuis l'accident de Fukushima». Cet article fait le retour d'expérience des stratégies, de la surveillance radiologique et des contremesures utilisées pour redémarrer les acticités agricoles et pour regagner la confiance des consommateurs.

Le $3^{\mathrm{e}}$ article de Fassert (2020) est intitulé «L'accident nucléaire de Fukushima : enjeux et contestations autour de la définition du zonage ». Cet article analyse en profondeur le zonage comme outil de gestion des territoires contaminés à Fukushima. Il démontre clairement comment la valeur seuil de $20 \mathrm{mSv}$ a été remise en question par la population et par les contre-experts qui l'ont tous considérée comme trop élevée.

Ces deux articles soulignent l'importance des dimensions sociales et humaines dans la gestion de ces situations très complexes de phase post-accidentelle nucléaire. Le manque de confiance de la population et d'autres parties prenantes (acteurs socio-économiques, associations non gouvernementales...) dans les capacités du gouvernement et des autorités à gérer la situation semble critique bien que les décisions soient prises sur des bases scientifiques. Ces deux articles montrent les progrès significatifs effectués ces dernières décennies en matière de compréhension de telles situations post-accidentelles et de radioprotection de la population.

\section{Significant progress in radiological protection}

In this first issue of 2020 of Radioprotection, we publish significant progress in radiological protection in the medical field and in the post-accidental phase of a nuclear accident.

The article by Teriitehau et al. (2020) is entitled "Reduction of patient radiation dose during percutaneous CT vertebroplasty: impact of a new computer-assisted navigation (CAN) system". This CAN system uses a field generator integrated into the patient referential and a magnetic receiver integrated into a needle holder guide. The CAN system allows a precise and secure needle insertion and consequently allows to significantly reduce both patient radiation exposure and procedure duration in percutaneous CT vertebroplasty. This CAN system is increasingly used in many other interventional radiology procedures and thus marks a breakthrough in radiological protection in the medical field.

A second article by Maître et al. (2020), is entitled "The management of contaminated goods in Japan since the Fukushima accident". This paper makes the experience feedback of the strategies, radiological monitoring and countermeasures set up to restart agricultural activities and to regain consumer confidence.

The third article by Fassert (2020) is entitled "The Fukushima nuclear accident: stakes and disputes for the definition of zoning". This article analyzes in depth the zoning as a tool of management of contaminated territories in Fukushima. It clearly demonstrates how the threshold value of $20 \mathrm{mSv}$ has been questioned by the population and by counter-experts who all considered it as too high.

These two papers highlight the importance of social and human dimensions in the very complex situation of a post-nuclear accident phase. The lack of population and other stakeholders (e.g., socio-economic actors, NGOS...) confidence in government's and authorities' capability to manage the situation seems critical although the decisions taken were based on scientific ground. These two papers show the significant progress made in the last decades regarding the comprehension of such post-accidental situations in terms of population radiological protection.

\section{Références}

Fasset C. 2020. L'accident nucléaire de Fukushima : enjeux et contestations autour de la définition du zonage. Radioprotection 55(1): 29-39. Maître M et al. 2020. The management of contaminated goods in Japan since the Fukushima accident. Radioprotection 55(1): 17-28.

Teriitehau C et al. 2020. Reduction of patient radiation dose during percutaneous CT vertebroplasty: Impact of a new computer-assisted navigation (CAN) system. Radioprotection 55(1): 11-16. 